\begin{tabular}{|c|c|c|}
\hline & $\begin{array}{c}\text { International Journal of Current Research in } \\
\text { Biosciences and Plant Biology } \\
\text { EXCELLENT } \\
\text { PUBLISHERS }\end{array}$ \\
Volume 5 - Number 3 (March-2018) ・ ISSN: 2349-8080 (Online) \\
Journal homepage: www.ijcrbp.com
\end{tabular}

Original Research Article

doi: https://doi.org/10.20546/ijcrbp.2018.503.003

\title{
Morpho-Anatomical Studies of Cleome monophylla L.
}

\author{
P. Abirami and P. Vijayashalini* \\ PG and Research Department of Botany, Vellalar College for Women (Autonomous), \\ Erode- 638 012, Tamil Nadu, India \\ ${ }^{*}$ Corresponding author.
}

\begin{tabular}{|c|c|}
\hline Article Info & ABSTRACT \\
\hline $\begin{array}{l}\text { Date of Acceptance: } \\
10 \text { February } 2018\end{array}$ & \multirow{4}{*}{$\begin{array}{l}\text { Cleome monophylla L. belongs to the family Cleomaceae (spindle flower family) and is } \\
\text { commonly used in traditional and folklore medicines for treating various diseases. The } \\
\text { present study investigated the morpho-anatomical characterization of leaf, stem, root } \\
\text { and powder of C. monophylla. The result revealed a special type of trichome called } \\
\text { shaggy-trichome frequently on the stem and other organs of the plants, anisocytic and } \\
\text { actinocytic type of stomata in the leaf. A large number of fibres, vessel elements, } \\
\text { tracheids and parenchyma cells were observed in the plant powder. }\end{array}$} \\
\hline $\begin{array}{l}\text { Date of Publication: } \\
06 \text { March } 2018\end{array}$ & \\
\hline Ke y w ords & \\
\hline $\begin{array}{l}\text { Actinocytic stomata } \\
\text { Cleome monophylla } \\
\text { Shaggy trichome } \\
\text { Spindle pod }\end{array}$ & \\
\hline
\end{tabular}

\section{Introduction}

Medicinal plants are the local heritage with global importance. The knowledge of medicinal plants has been accumulated in the course of many centuries based on the different medicinal system such as Ayurveda, Unani, Siddha and Homeopathy. Ethnomedicinal practices are preferred largely because medicinal plants are less expensive, readily available, reliable and they are considered to have fewer side effects than modern medicines. Herbal remedies are considered the oldest forms of healthcare known to mankind on this earth. Earlier to the development of modern medicine, the traditional systems of medicine that have evolved over the centuries within various communities are still maintained as a great traditional knowledge base in herbal medicines (Mukherjee and Wahil, 2006). Herbal drugs constitute only those traditional medicines which primarily use medicinal plant preparations for therapy (Kamboj, 2000).

Microscopic method is one of the simplest and cheapest methods to start with for establishing the correct identity of the source materials (Kumar et al., 2011). Plant anatomy is now frequently investigated at the cellular level, and often involves the sectioning of tissues and microscopy (Evert et al., 2006; Kokate, 2001). Cleome monophylla L. belongs to the family Cleomaceae (spindle flower 
family) and is commonly used in traditional and folklore medicines for treating various diseases. It is a single leaved species in the compound leaf genera. It is commonly called as spindle pod and Tamil vernacular name is Naaikadugu and Ellukku sakkalathi. The synonym is Cleome cordata, $C$. subcordata and $C$. massae. It is an erect herb up to $90 \mathrm{~cm}$, branchlets glandular and pubescent. $C$. monophylla cures ulcer, boils, wounds, cough, headache, swellings, hasten maturation, ear discharges, anthelmintic (Kalaichelvi et al., 2017), fever (Tamilselvi et al., 2016; Tugume et al., 2016), headache (Segawa and Kasenene, 2007) and bile enlargement (Bandana and Sudhanshu, 2000). The leaf extract of $C$. monophylla had anti-HIV-1 reverse transcriptase activity (Hurinanthan, 2013). The plant possesses anti inflammatory, anthelmintic and antidermatosis activity (Khare, 2007).

\section{Materials and methods}

\section{Collection and authentication of specimen}

The plant Cleome monophylla L. was collected from Eratti, Burgur range of Reserve forest, Erode District, Tamil Nadu, India. The plant was identified and authenticated taxonomically with the help of Flora of the Presidency of Madras (Gamble and Fischer, 1915-1936) and The Flora of the Tamil Nadu Carnatic (Matthew, 1983) and also confirmed with the help of type specimens available in the Herbarium of Botanical Survey of India, Southern region, Coimbatore, Tamil Nadu. The Herbarium number in BSI is BSI/SRC/5/23/2016/Tech./1818.

\section{Microscopic studies}

The required samples of different organs were cut and removed from the plant and fixed in FAA (Farmalin-5ml+ Acetic acid-5ml $+70 \%$ Ethyl alcohol-90ml). After $24 \mathrm{hrs}$ of fixing, the specimens were dehydrated with graded series of tertiary Butyl alcohol as per the schedule (Sass, 1940). Infiltrations of the specimens were carried by gradual addition of paraffin wax (melting point 58$60^{\circ} \mathrm{C}$ ) until TBA solution attained super saturation. The specimens were cast into paraffin blocks.

\section{Sectioning}

The paraffin embedded specimens were sectioned with the help of Rotary Microtome. The thickness of the sections was 10-12 $\mu \mathrm{m}$. Dewaxing of the sections was by customary procedure (Johansen, 1940). The sections were stained with Toluidine blue (O'Brien et al., 1964). Wherever necessary sections were also stained with safranin and Fastgreen and IKI (for Starch). For studying the stomatal morphology, venation pattern and trichome distribution, paradermal sections (sections taken parallel to the surface of leaf) as well as clearing of leaf with $5 \%$ sodium hydroxide or epidermal peeling by partial maceration employing Jeffrey's maceration fluid were prepared. Glycerine mounted temporary preparations were made for macerated/cleared materials.

\section{Powder study}

Plant sample was made into coarse powder and was immersed in warm water in order to remove the air in the cells. A pinch of the powder was kept on microscope slide and a drop of safranin $(0.5 \%)$ was added to the powder and it was rinsed in water to remove the excess of safranin. A drop of dilute glycerine was added and a cover glass was put on the material and the slide was observed under the microscope. Powdered materials of different parts were cleared with $\mathrm{NaOH}$ and mounted in glycerine medium after staining. Different cell component were studied and measured.

\section{Photomicrographs}

Microscopic descriptions of tissues were supplemented with micrographs wherever necessary. Photographs of different magnifications were taken with Nikon labphoto 2 microscopic Unit. For normal observations bright field was used. For the study of crystals, starch grains and lignified cells, polarized light was employed. Magnifications of the figures are indicated by the scale-bars. Descriptive terms of the anatomical features are as given in the standard Anatomy books (Easu, 1964). 


\section{Results}

The morphology of the C.monophylla was given in the Fig. 1 (A, B, C and D). It shows the habit of the plant, closure view of the flowering twig, fruit and seeds. The vegetative and reproductive characteristics of $C$. monophylla is given in Table 1.

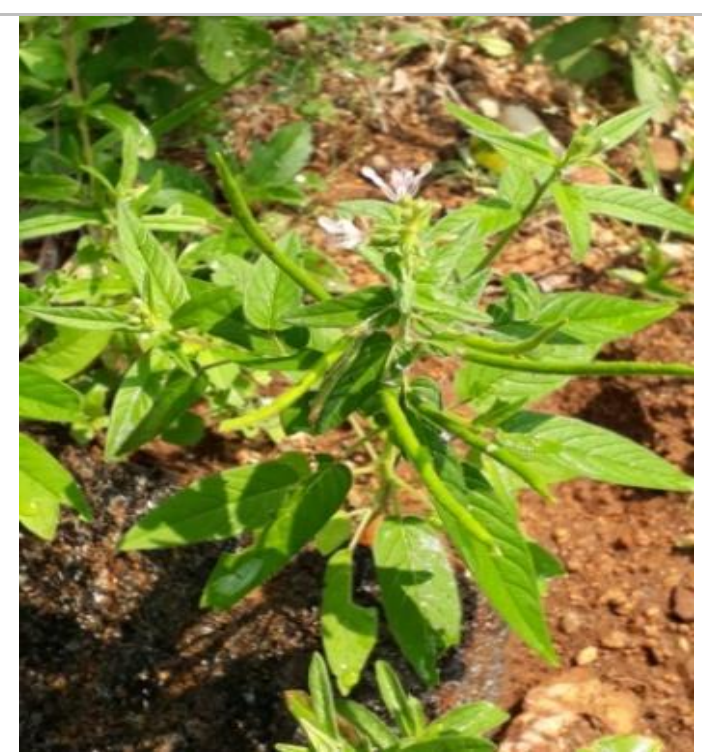

(A)

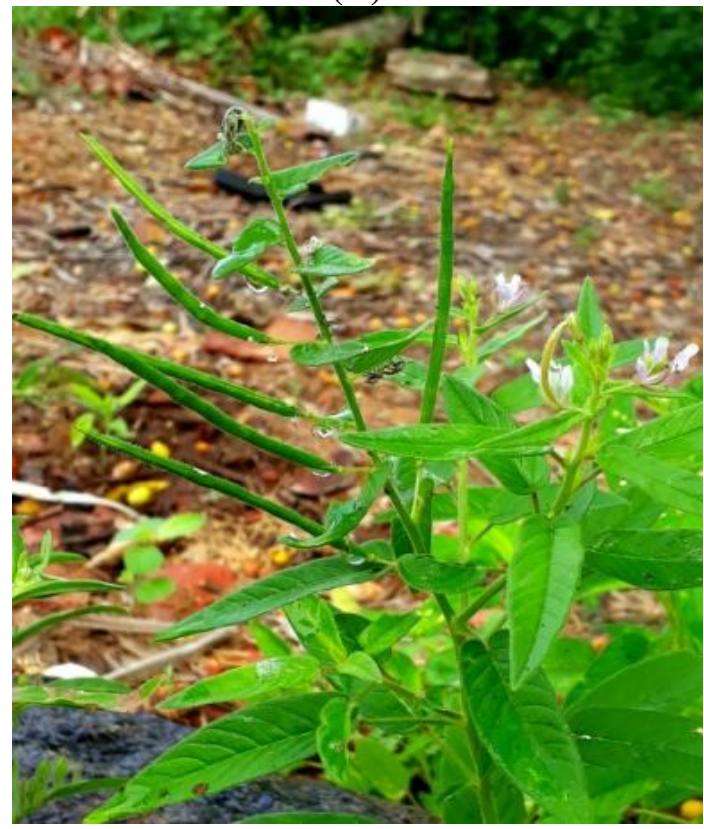

(C)

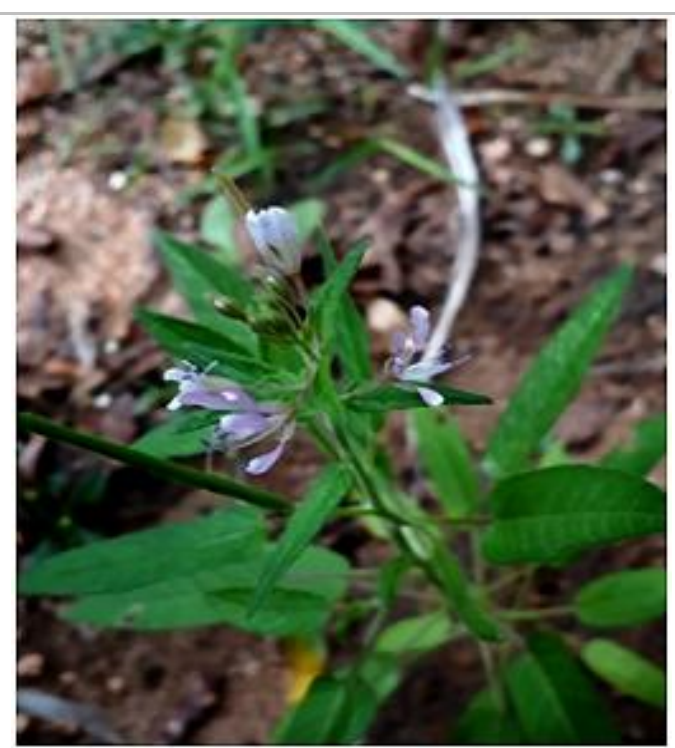

(B)

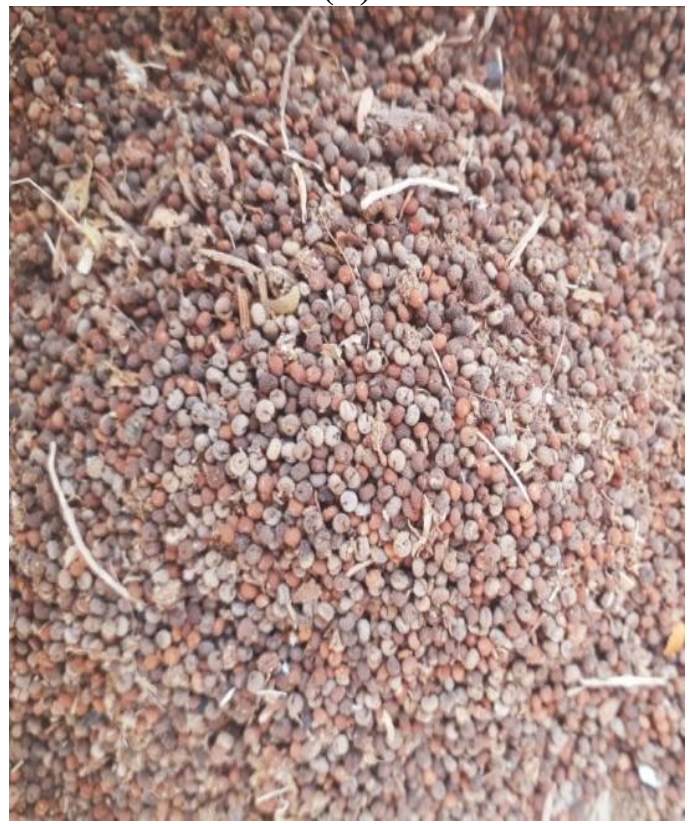

(D)

Fig. 1: Cleome monophylla L. (A) Habit; (B) A flowering twig; (C) A twig with fruits; (D) Seeds.

\section{Leaf}

In Sectional view, the leaf exhibits prominent midrib, lateral vein and uniformly thin lamina. The midrib has deep adaxial groove due to folding of the lamina and thick hemispherical abaxial part
(Fig. 2-A). The midrib is $450 \mu \mathrm{m}$ in vertical plane and $650 \mu \mathrm{m}$ in horizontal plane. The midrib consists of a thin layer of epidermis which has thin walled circular cells. One or two layers of epidermal and sub epidermal cells in the adaxial groove are small and thick walled. The ground cells are polygonal, 
thin walled and compact. The vascular system includes three fairly discrete collateral vascular bundles located in middle portion of the midrib. The three bundles form a shallow arc of the three bundles the middle bundle is smaller than the lateral bundles. The vascular bundles are vertically elongated. The xylem portion includes several vertical lines of circular thick walled vessels and a small mass of phloem elements located at the lower end of the xylem. At the phloem end of the bundle a small sclerenchyma cap is seen in all three bundles (Fig.2-B).

Table 1. Macroscopical characters of Cleome monophylla L.

\begin{tabular}{|c|c|c|}
\hline Part of the plant & Characters noted & Observation \\
\hline \multirow[t]{12}{*}{ Leaf } & Colour & Green \\
\hline & Odour & Aromatic \\
\hline & Taste & Acrid \\
\hline & Size & $3-6.5 \times 1-2 \mathrm{~cm}$ \\
\hline & Shape & Linear oblong \\
\hline & Texture & Rough pubescent \\
\hline & Fracture & Smooth \\
\hline & Apex & Acute \\
\hline & Margin & Ciliate \\
\hline & Arrangement & Alternate spiral \\
\hline & Appearance & Soft \\
\hline & Petiole & $5 \mathrm{~cm}$ \\
\hline \multirow[t]{7}{*}{ Stem } & Colour & Green \\
\hline & Odour & Aromatic \\
\hline & Taste & Acrid \\
\hline & Size & $1-2 \mathrm{ft}$, erect \\
\hline & Shape & Angular \\
\hline & Texture & Rough pubescent \\
\hline & Fracture & Hard \\
\hline \multirow[t]{7}{*}{ Inflorescence } & Colour & Pinkish purple \\
\hline & Flower & Terminal racemes \\
\hline & Sepals & 4 , linear $5 \mathrm{~mm}$ \\
\hline & Petals & 4 , oblong $8 \mathrm{~mm}$ \\
\hline & Pedicel & $1 \mathrm{~cm}$ \\
\hline & Stamens & 6 \\
\hline & Ovary & Superior, $8 \mathrm{~mm}$, glandular \\
\hline \multirow[t]{2}{*}{ Fruit } & Colour & Green \\
\hline & Type & Pod \\
\hline \multirow[t]{2}{*}{ Seed } & Colour & Brown \\
\hline & Type & Rugose \\
\hline \multirow[t]{7}{*}{ Root } & Colour & Brown \\
\hline & Odour & Aromatic \\
\hline & Taste & Acrid \\
\hline & Size & $20-30 \mathrm{~cm}$ \\
\hline & Shape & Angular \\
\hline & Texture & Rough \\
\hline & Fracture & Hard \\
\hline
\end{tabular}




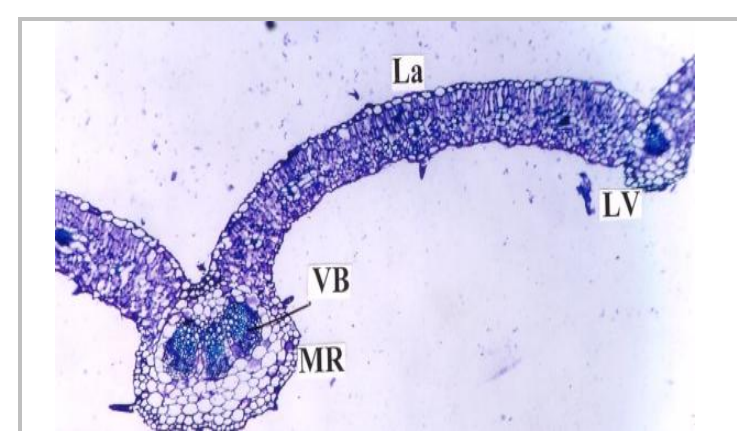

(A)

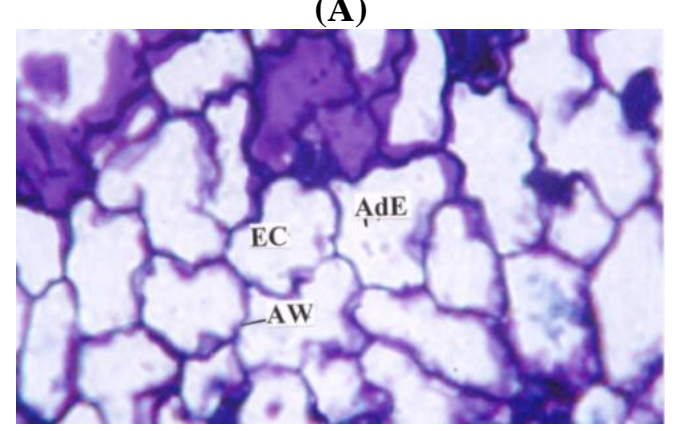

(C)

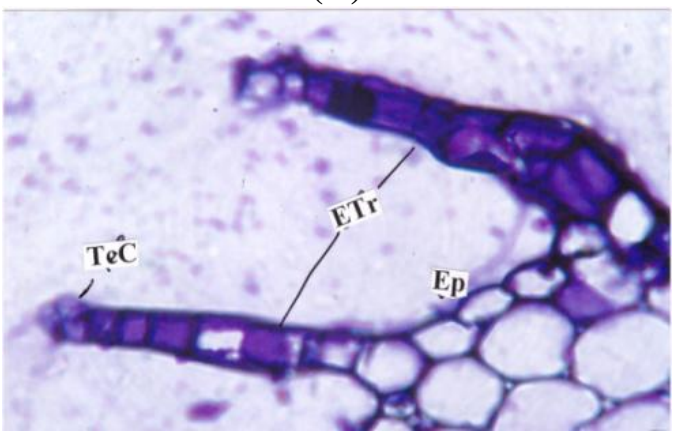

(E)

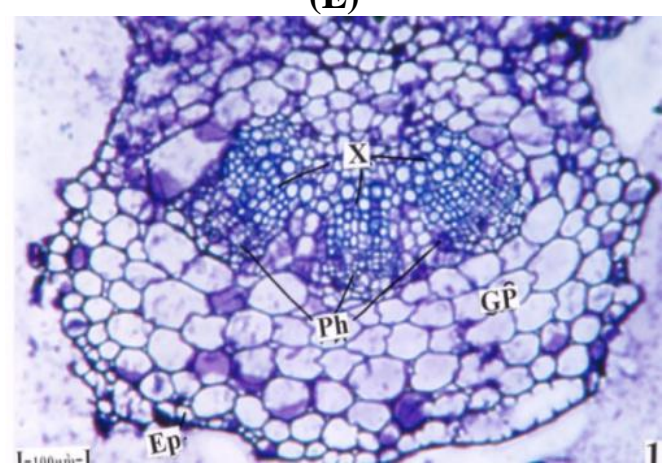

(G)

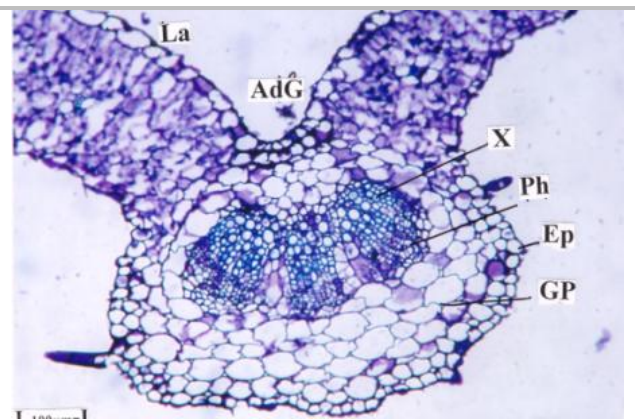

(B)

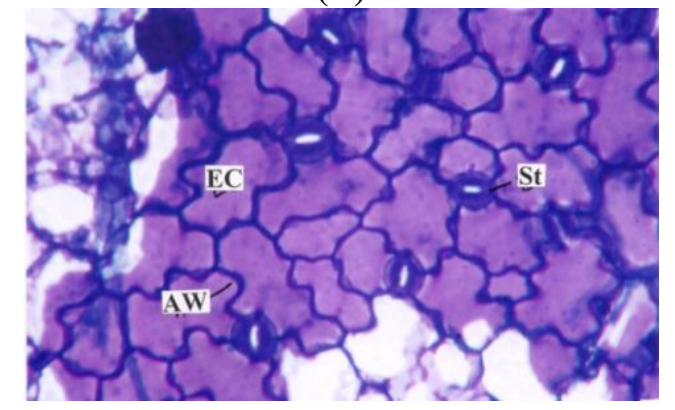

(D)

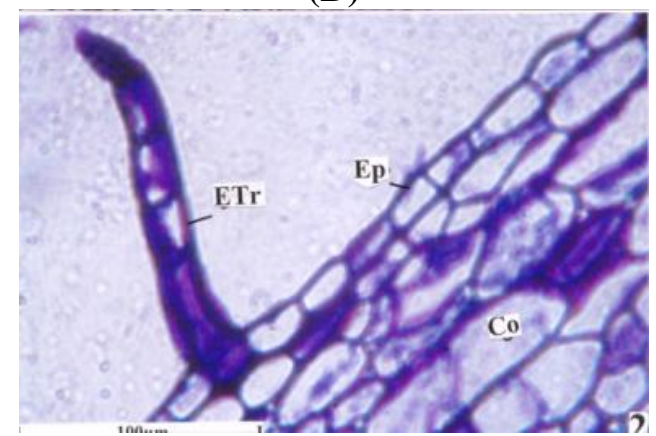

(F)

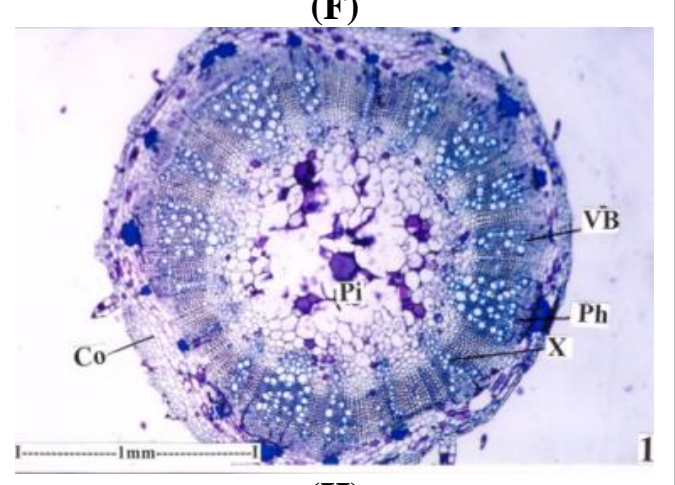

(H)

Fig. 2: Anatomical features of Cleome monophylla: (A) T.S of leaf through midrib; (B) T.S. of midrib; (C) Adaxial epidermis in surface view; (D) Abaxial epidermis surface view showing stoma; (E) Trichomes on epidermis of leaf; (F) Uniseriate trichome; (G) T.S. of petiole; (H) T.S. of stem.

\section{Epidermal tissues and Stomata}

The adaxial epidermis is apostomatic (without stomata). The epidermal cells are wide polygonal in out line with thin undulate. The epidermal cells have fairly thick anticlinal walls which are wavy in outline (Fig.2-C). The stomata are diffusely distributed. The stomata are either anisocytic or 
actinocytic (Fig.2-D). Different types of epidermal trichomes are seen on the lamina and midrib. The trichomes are mostly nonglandular type, multicellular uniseriate and unbranched (Fig.2-E, F).

\section{Petiole}

The petiole is basket shaped in sectional view with shallow adaxial groove (Fig.2-G). The abaxial part of the petiole is thick and wide and semicircular. It is $650 \mu \mathrm{m}$ thick and $900 \mu \mathrm{m}$ wide. The petiole consists of thin epidermal layer of small squar/ circular cells with prominent cuticle. The ground tissue consists of wide, circular, thin walled parenchyma cells. The vascular system includes a thick and wide area of three segmented vascular bundles. The xylem elements are narrow, thick walled and compact. At the lower end of the bundles occur small clusters of phloem elements. Sclerenchyma cells occur in thin layer adjacent to the phloem. In between the vascular bundles occur narrow passages of large and thick walled cells.

\section{Stem}

The stem is $2.5 \mathrm{~mm}$ thick. It consists of epidermis, cortex, hallow vascular cylinder and wide pith (Fig.2-H).The epidermal layer consists of small, thin walled spindle shaped cells and the cortex has about five layers polygonal, compact parenchyma cells. There are circular, thick masses of sclerenchyma strands in the inner most part of the cortex. The vascular cylinder includes small strands of phloem elements located all around the xylem cylinder. The phloem strands are closely attached with the fibre strands. The xylem cylinder consists of secondary xylem vessels and xylem fibres. Along the inner border of the secondary xylem occurs sever small wedge shaped primary xylem strands (Fig.3-A).

\section{Epidermal trichomes}

A special type of trichome called shaggy- trichome is frequently seen on the stem and other organs of the plants. The shaggy trichome is multiseriate thick, unbranched (Fig.3-B). The trichome is thick at the base and gradually tapers at the tip. The trichome is $200 \mu \mathrm{m}$ long and $60 \mu \mathrm{m}$ at the base.

\section{Thin young Root}

The thin young root is $650 \mu \mathrm{m}$ in diameter. It is slightly wavy in outline. It consists of thin epidermal layers of small spindle shaped cells. The cortical zone is four or five layered parenchymatous cells. The cortical cells are various in shape and size and are compact thin walled. Secondary phloem includes thin radial rows of five or six phloem elements Secondary phloem surrounds a solid cylinder of secondary xylem cylinder. The secondary xylem includes diffusely distributed vessels in the thick walled lignified xylem fibres. The vessels are wide, narrow, circular and thick walled. The wide vessels are $55 \mu \mathrm{m}$ in diameter, the narrow vessels are $15 \mu \mathrm{m}$ in diameter (Fig.3-C).

\section{Thick and old root}

The old root is $2 \mathrm{~mm}$ thick, the epidermal layer is broken and peeled off. The cortical zone is $40 \mu \mathrm{m}$ thick and intact. Secondary phloem is in continuous cylinder and it is $70 \mu \mathrm{m}$ thick, secondary xylem cylinder is $1.5 \mathrm{~mm}$ thick (Fig.3-D).The cortical zone is differentiated into outer part of four layered periderm and inner, tangentially compressed narrow, compact parenchyma cells dispersed in the inner part of the cortex. Small patches of sclerenchyma cells are secondary phloem elements include sieve elements and phloem parenchyma cells (Fig.3-E). The companion cells are very small and they are laterally attached to sieve cells.

Secondary xylem includes vessels and xylem rays and xylem fibres. In the central core of the root occurs dense cluster of small vessels. External to the central core, occur diffusely distributed wide vessels. Xylem fibres are circular or angular, highly thick walled and have narrow lumen and occur in compact straight lines. The fibre walls are lignified. Xylem rays are thin and narrow, thin walled and run straight within the secondary xylem elements (Fig.3-F). 


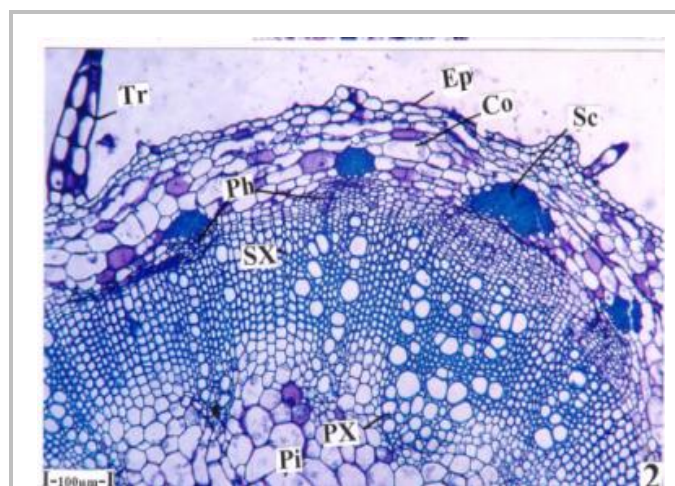

(A)

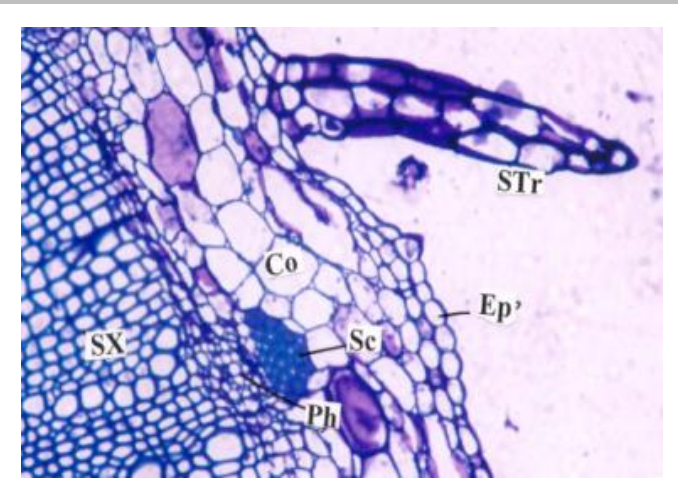

(B)

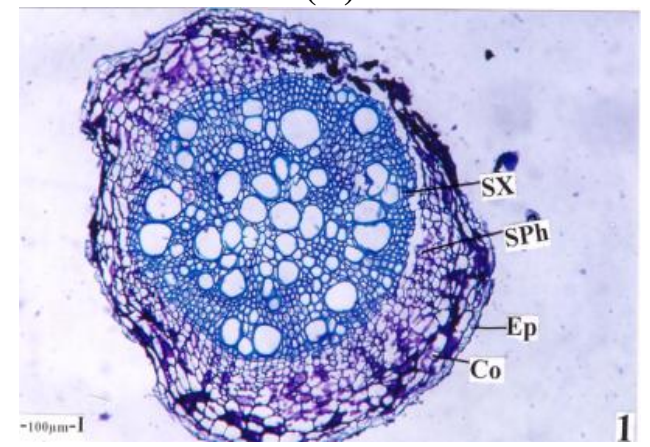

(C)

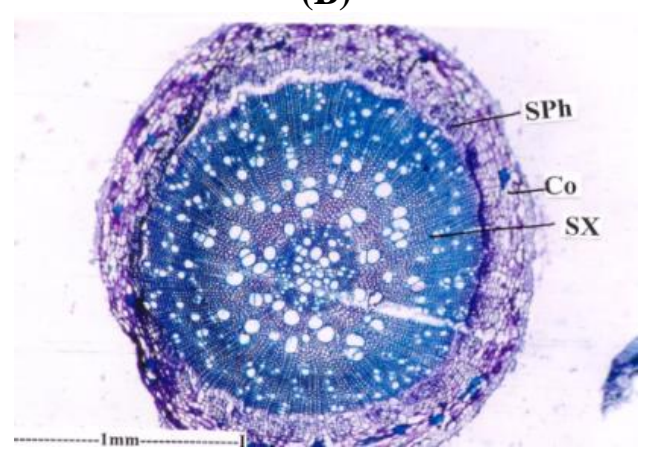

(D)

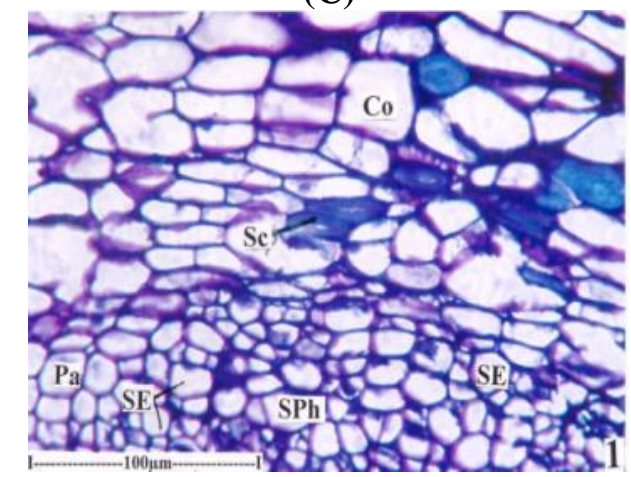

(E)

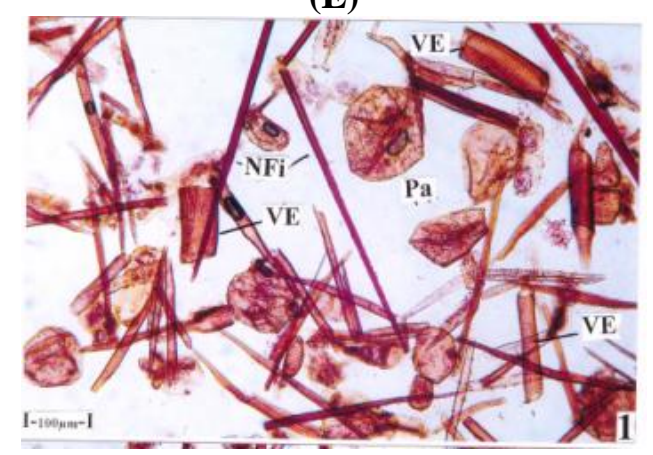

(G)

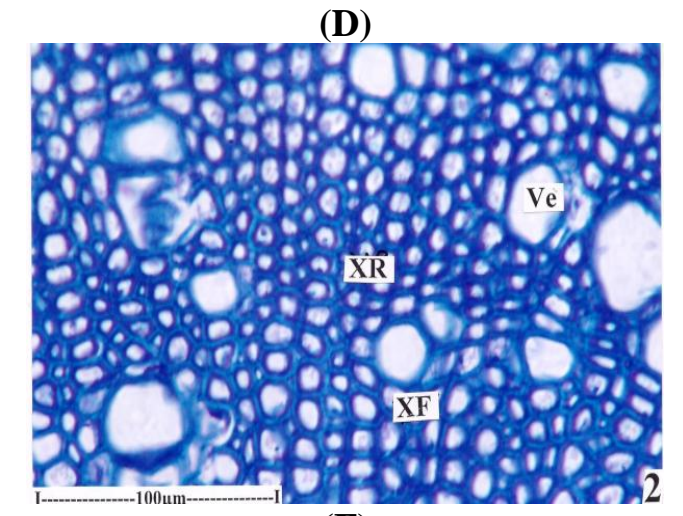

(F)

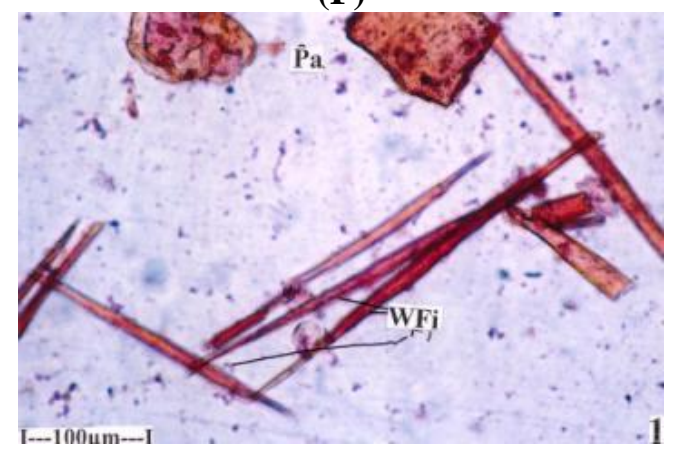

(H)

Fig. 3: Anatomical features of Cleome monophylla: (A) T.S. of stem sector; (B) Shaggy trichome; (C) T.S. of thin root; (D) T.S. of thick root; (E) Phloem enlarged; (F) T.S. of thick root secondary xylem enlarged; (G) Powder showing fibres, parenchymatous vessel elements; (H) Fibres. 


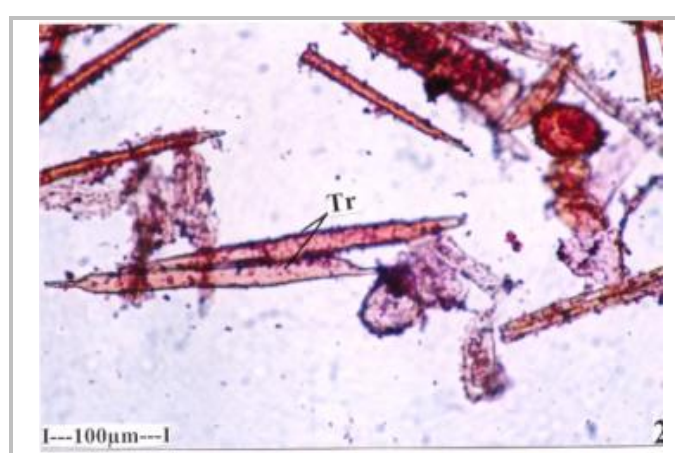

(A)

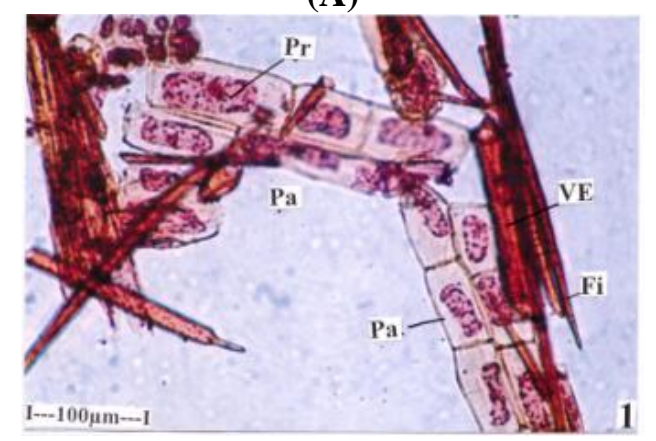

(C)

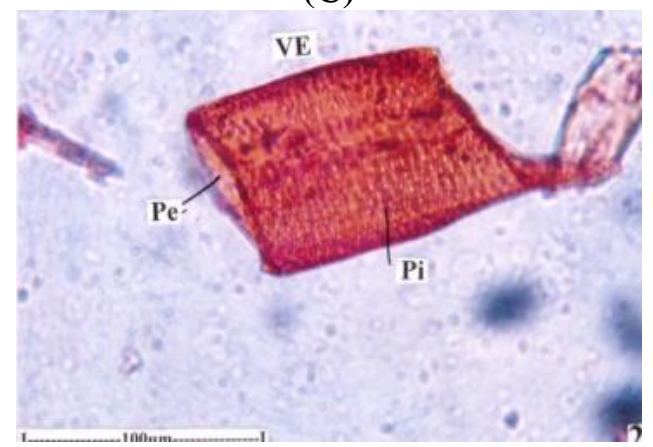

(E)

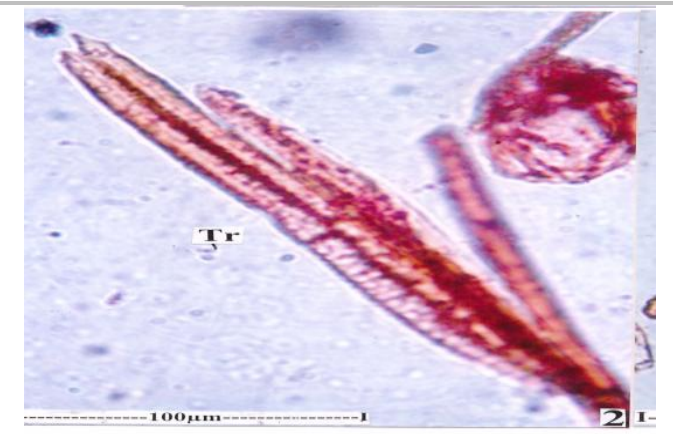

(B)

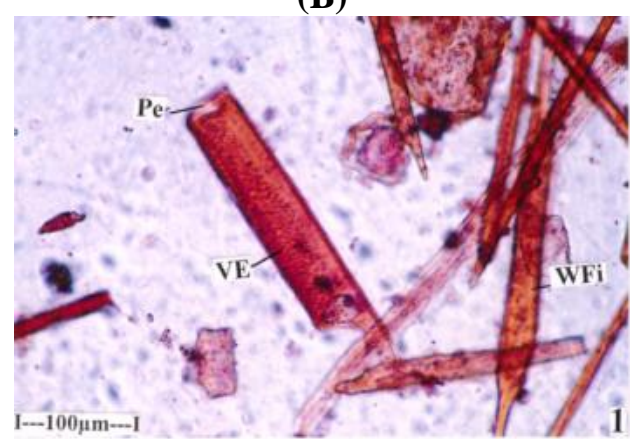

(D)

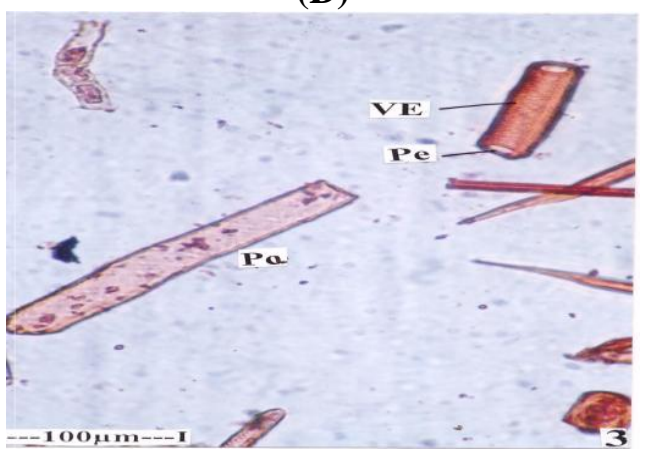

(F)

Fig. 4: Parenchyma and xylem components of Cleome monophylla: (A) Parenchyma strand; (B) Septate tracheids; (C) Tracheids; (D) Narrow cylindrical vessel elements; (E) Short wide vessel elements; (F) Parenchyma and vessel elements (Abbreviations: AdG- Adaxial Groove, Ep- Epidermis, GP- Ground Parenchyma, La- Lamina, LV- Lateral view, MR- Midrib, Ph- Phloem, Sc- Sclerenchyma, VB- Vascular Bundle, X- Xylem, AbE- Abaxial epidermis, AW- Anticlinal Wall, St- Stomata, ETr- Epidermal Trichome, , GP- Ground Parenchyma, Tec- Terminal Cell, Pi-Pith, Tr- Trichome, SX- Secondary Xylem, PX- Primary Xylem, SPh- Secondary Phloem, STr- Shaggy Trichome, Co- Cortex, Pa- parenchyma, SESieve Elements, Pe- perforation, Ve- Vessel, WFi- Wide Fibre).

\section{Powder microscopy}

The following elements were seen under the microscope:

A large number of fibres, vessel elements and parenchyma cells are observed under the microscope (Fig.3-G). i) Fibres: Two types of fibres are seen. Some fibres are narrow, thick walled with reduced lumen, the narrow fibres are $450 \mu \mathrm{m}$ long and $10 \mu \mathrm{m}$ wide.

The wide fibres have thin walled and wide lumen. The wide fibres are $320 \mu \mathrm{m}$ long and $20 \mu \mathrm{m}$ wide (Fig.3-H). 
ii) Parenchyma cells- Two types of parenchyma cells are observed. Some are spherical or polyhedral in shape they have thin walls and dense cytoplasm (Fig.4-A).

The second types of parenchyma cells are rectangular and elongated. They are seen either in vertical strands or isolated cells. The strand parenchyma cells have thin walls and dense aggregation of protoplast. The isolated parenchyma cells have granular cell inclusions.

iii) Tracheids are common in powder, they are long, cylindrical cells with tapering ends. They have circular bordered lateral pits. The tracheids are $300 \mu \mathrm{m}$ long and $20 \mu \mathrm{m}$ wide (Fig.4-B, C).

iv) Vessel elements- Vessel elements are frequent in the powder. Some vessel elements are narrowly cylindrical and long (Fig.4-D). The second type of vessel elements is wide, short and barrel shaped (Plate-IV-5,6). The lateral wall pits of elliptical and multiseriate. The end wall perforations are wide, circular, horizontal or slightly oblique.

\section{Discussion}

The present findings may facilitate identification of certain novel compounds in the plant material. The adaxial epidermis is apostomatic (without stomata). The abaxial epidermis has anisocytic or actinocytic stomata. The stomatal pore is broad and elliptical in outline. Easu (1979) and Gupta and Rao (2012) reported the glandular and simple covering trichomes and anomocytic stomata in Cleome viscosa. The lower and upper epidermis contains anomocytic stomata and glandular trichomes. The stomata size at X40 objective is $45 \mu \mathrm{m}$, while the trichome size is $480 \mu \mathrm{m}$ at $\mathrm{X} 10$ objective in Cleome viscosa (Onoja, 2016). Different types of epidermal trichomes are seen on the lamina and midrib mostly nonglandular type multicellular uniseriate and unbranched were seen. Similar findings were reported in Cleome viscosa (Edeoga et al., 2009).

In the leaves of $C$. viscosa, multicellular trichomes were observed, these trichomes were large and long with a club shaped head and glandular basal end. These glandular hairs have earlier been described and this feature separates it from other Cleome species (Jansen, 2004; Metcalfe and Chalk, 1983). Foliar epidermal cells, stomatal cells and trichome complexes in some Indian species of Cleome $(C$. aspera Koen. ex DC. C. chelidonii L.f., C. felina L.f., C. monophylla L.,C. gynandra L., C. tenella L.f. and $C$. Viscosa and six trichome types noted (uniseriate capitate, uniseriate cylindrical, biseriate capitate, multiseriate capitate, multiseriate clavate and multiseriate conical trichomes) (Jelani et al., 1990). The petiole of $C$. monophylla is basket shaped in sectional view with shallow adaxial groove. In $C$. rutidosperma petiole comprised five U-shaped free open collateral vascular bundles which formed an arc or semicircle (Okonwu et al., 2017). Shaggy- trichomes are frequently seen in the stem of $C$. monophylla, similar findings were reported in $C$. gynandra (Mishra et al., 2011; Anbazhagi et al., 2009). In the powder study spherical, polyhedral type of parenchyma cells were observed, similar findings were reported in Cleome viscosa (Onoja, 2016).

\section{Conclusion}

Cleome monophylla is a medicinal plant and used in various indigenous medicines and formulations of Siddha and Ayurveda. The anatomical studies are helpful for the identification and characterization of plant material. The present investigation may provide valuable source of information and help in standardizing the phytocompounds of this plant and will give an idea for future applications.

\section{Conflict of interest statement}

Authors declare that they have no conflict of interest.

\section{References}

Anbazhagi, T., Kadavul, K., Suguna, G., Petrus, A.J.A., 2009. Studies on the pharmacognostical and in vitro antioxidant potential of Cleome gynandra L. leaves. Nat. Product. Rad. 8(2), 
151-157.

Bandana, K., Sudhanshu, K., 2000. A checklist of some leafy vegetables used by tribals in and around Ranchi, Jharkhand. Zoos' Print. J. 16(3), 442-444.

Easu, K., 1964. Plant Anatomy. John Wiley and Sons, New York. 767p.

Easu, K. 1979. Anatomy of Seed Plants. John Wiley and Sons, New York. 550p.

Edeoga, H.O., Omosun, G., Osuagwu, G.G.E., Mbaebie, B.O., Madu, B.A., 2009. Micromorphological characters of the vegetative and floral organs of some Cleome species from Nigeria. Amer.-Eur. J. Sci. Res. 4(3), 124-127.

Evert, R. F., 2006. Esau's Plant Anatomy: Meristems, Cells, and Tissues of the Plant Body - Their Structure, Function and Development. Wiley, Hoboken, New Jersey.

Gamble, J.S., Fischer, C.E.C., 1915-1936. The Flora of the Presidency of Madras. Vol-I, II and III., Adlard\& Son Ltd., London.

Gupta, P.C., Rao, Ch.V., 2012. Pharmacognostical studies on Cleome viscosa Linn. Ind. J. Nat. Prod. Res. 3(4), 527-534.

Hurinanthan, V., 2013. Anti-HIV activity of selected South African medicinal plants [Ph.D. dissertation].

Jansen, P.C., 2004. Cleome rutidosperma L. and $C$. viscosa L. In: Plant Resources of Tropical Africa 2. Vegetables (Eds.: Grubben, G. J. H., Denton, O. A.). Prota Foundation, Backhurys Publishers, Leiden Netherlands, CTA Wageningen.

Jelani, S., Leelavathi, P., Prabhakar, M., 1990. Foliar epidermis in relation to taxonomy of Cleome (Capparaceae). Asian J. Plant. Sci. 2(2), 13-24.

Johansen, D.A., 1940. Plant Microtechnique. Mc Graw Hill Book Co., New York.

O’Brien, T.P., Feder, N., McCull, M.E., 1964. Polychromatic staining of plant cell walls by toluidine blue-O. Protoplasma. 59, 364-373.

Kalaichelvi, K., Dhivya, S.M., Vijayashalini, P., 2017. Indigenous knowledge on herbaceous medicinal plants among the local people of Mavanatham and Ittarai villages, Thalamalai hills, Sathyamangalam reserve forest range, Tamil Nadu, India. Int. J. Plant. Anim. Environ. Sci. 7(3), 10-18.

Kamboj, V.P., 2000. Herbal medicine. Curr. Sci. 78(1), 35-51.

Khare, C.P., 2007. Indian Medicinal Plants-An Illustrated Dictionary. First Indian Reprint, Springer (India) Pvt. Ltd., New Delhi.

Kokate, C.K., 2001. Practical Pharmacognosy, $4^{\text {th }}$ Edn. Vallabh Prakashan, Delhi. pp.107-111, 123-125, 130.

Kumar, S., Kumar, V., Prakash, O., 2011. Microscopic evaluation and physicochemical analysis of Dillenia indica leaf. Asian. Pac. J. Trop. Biomed. . 1(5), 337-340.

Matthew, K.M., 1983. The Flora of the Tamil Nadu Carnatic, Vol- III. Part- I, II and III. The Rapinet Herbarium, St. Joseph's College, Thiruchirapalli, India.

Metcalfe C.R., Chalk, L., 1983. Anatomy of in Portulacaceae (Centrospermae). Feddes Repert, Dicotyledons. $2^{\text {nd }}$ Edn. Clarendon Press, Oxford.

Mishra, S.S., Moharana, S.K., Dash, M.R., 2011. Review on Cleome gynandra. Int. J. Res. Pharma. Chem. 1(3), 681-689.

Mukherjee, P.K., Wahil, A., 2006. Integrated approaches towards drug development from Ayurveda and other systems of medicine. J. Ethnopharmacol. 103, 25-35.

Okonwu, K., Ekeke, C., Mensah, S.I., 2017. Micromorphological and phytochemical studies on Cleome rutidosperma L. J. Adv. Biol. Biotech. 11(3), 1-8.

Onoja, O.J., 2016. Morpho anatomical study on Cleome viscosa L. (Cleomaceae). J. Pharmacog. Phytochem. 5(4), 13-16.

Sass, J.E., 1940. Elements of Botanical Micro technique. McGraw Hill Book Co., New York. 222p.

Ssegawa, P., Kasenene, J.M., 2007. Medicinal plant diversity and uses in the Sango bay area, Southern Uganda. J. Ethno. Pharmacol. 113, 521-540.

Tamilselvi, S.S., Venkatachalapathi, A., Paulsamy, S., 2016. Ethnomedicinal plants used by irula tribes of Maruthamalai hills of Coimbatore 
District, Western Ghats, India. Int. J. Pharm. Bio. Sci. 7(3-B), 533-553.

Tugume, P., Kakudidi, E.K., Buyinza, M., Namaalwa, J., Kamatenesi, M., Mucunguzi, P.,
Kalema, J., 2016. Ethnobotanical survey of medicinal plant species used by communities around Mabira central forest reserve. Uganda.J. Ethnobiol. Ethnomed. 12(5), 1-28.

\section{How to cite this article:}

Abirami, P., Vijayashalini, P., 2018. Morpho-anatomical studies of Cleome monophylla L. Int. J. Curr. Res. Biosci. Plant Biol. 5(3), 21-31. doi: https://doi.org/10.20546/ijcrbp.2018.503.003 